\title{
The Reinforcement of Farmer Capacity in Merbau Village, Bunut Sub Distrct, Pelalawan, Riau in Peat Land Restoring Program
}

\author{
Eksa Rusdiyana \\ Agricultural Faculty \\ Universitas Sebelas Maret \\ Surakarta, Indonesia \\ eksarusdiyana@gmail.com \\ Ernoiz Antriyandarti \\ Agricultural Faculty \\ Universitas Sebelas Maret \\ Surakarta, Indonesia \\ eksarusdiyana@gmail.com
}

\author{
Joko Sutrisno \\ Agricultural Faculty \\ Universitas Sebelas Maret \\ Surakarta, Indonesia \\ eksarusdiyana@gmail.com \\ Nuning Setyowati \\ Agricultural Faculty \\ Universitas Sebelas Maret \\ Surakarta, Indonesia \\ eksarusdiyana@gmail.com
}

\author{
Endang Siti Rahayu \\ Agricultural Faculty \\ Universitas Sebelas Maret \\ Surakarta, Indonesia \\ eksarusdiyana@gmail.com \\ Isti Khomah \\ Agricultural Faculty \\ Universitas Sebelas Maret \\ Surakarta, Indonesia \\ eksarusdiyana@gmail.com
}

\begin{abstract}
This research aims to find out the effect of farmer behavior reinforcement on the attempt of restoring peat land. This study was an action research using participatory rural appraisal (PRA) with People of Merbau Village, Bunut, Pelalawan, Riau being the participants. Data was collected using interview and focus group discussion (FGD) with peat moss land farmers, village government, female farmer group, agricultural extension officers, and small- and medium-scale employers being the representative participants. The result of research showed that community behavior in utilizing peat land for ind ustrial land gives the larger opportunity of burning peat land during dry season annually. Thus, there should be another alternative livelihood in peat land corresponding to community's local potency. The reinforcement of farmer behavior in peat land restoring program can be improved through the following programs: (1) non-oil palm (palm oil) and rubber farming plant enrichment pilot project (paludikultur) that is peat land-friendly, (2) the establishment of Merbau Jaya farmer group (deep, medium, and shallow peat land farmer groups), and (3) the reinforcement of new livelihood based on cassava and pineapple local potencies (the reinforcement of SME institution and training for paludikultur processed product diversification).
\end{abstract}

Keywords: Capacity, Farmer, Peat land, Reinforcement, Restorat

\section{INTRODUCTION}

Indonesia's swamp area is \pm 33.4 millions hectare wide, consisting of 14 millions hectare peat moss, 6 millions hectare sulfate acid and saline land, and 13.4 millions hectare lowland. Indonesia is the 4 th country with widest peat moss swamp in the world, about 17.2 millions hectare, following Canada (170 millions hectare), Soviet Union (150 millions hectare), and United States of America (40 millions hectare) (Najiyati). The failure of a million hectare peat moss land development in 1995 era should give the community and Indonesian government a lesson in order to manage peat moss land more wisely [1]. Peat moss land fire in Indonesia becomes an annual disaster harmful to
Malaysia, Singapura, and Brunei Darussalam as well. The main cause of fire relates to human activity, extreme climate condition affected by El Nino during dry season and biophysical condition of degraded land. In Indonesia, fire impacts on social, cultural, economic, and political aspects [2]. A good attempt of managing land can be taken by improving an attempt of conserving farming land and operating the assignment of eternal farmland corresponding to Farming, Fishery, and Forestry Revitalization [3]. The attempt of revitalizing peat moss can be taken by finding an alternative non-palm oil and non-rubber farming by finding other commodities corresponding to peat moss land. The reinforcement of farmer group behaviour is often different and should be adjusted with local character, so that an attempt is required to reinforce the typical behaviour of peat moss land farmers different from that of rice field or dry field farmers in general.

The development of other livelihood than palm oil and rubber is expected to reduce and to move peat moss land farmers to other farming activities that are more environment-friendly and sustainable. Merbau Village, Bunut Sub District, Pelalawan, Riau is an area of peat moss restoration model program development with non-palm oil and non-rubber farming development model. This research aimed to see the effect of the reinforcement of farmers' behaviour in peat moss land restoration program in Merbau Village. This development model is expected to create new sustainable farming.

\section{METHODS}

This study was an action research using participatory rural appraisal (PRA). PRA method requires the partner community to share, to improve, and to analyze each other the knowledge they have about their condition and life, and to develop plan and to take real action [4]. Basic principles of PRA method are, among others: learning and sharing 
experience with each other, the involvement of all members and information, outsiders as facilitator, triangulation concept, and outcome optimization, practical orientation and program sustainability [5]. PRA approach aims to make the members of community the author, planner, and executor of a program. In addition, PRA approach will lead to the achievement of the compatibility and expediency of program to the people's need, thereby ensuring the sustainability of program. The form of partnership established between program facilitator (Sebelas Maret University team in collaboration with Peat Moss Restoration Agency) and farmer group in Merbau Village, Bunut Sub District, Pelalawan Regency. The program was conducted in 2017 for 6 months. The procedure implemented in PRA included: focus group discussion, activity plan development, activity implementation and program evaluation.

Data was collected using interview and focus group discussion (FGD) with the representative participants consisting of peat moss land farmers, village government, female farmer group, agricultural extension officers, and small- and medium-scale employers. Meanwhile, the procedure of PRA included focus group discussion, action activity, and monitoring and evaluation. FGD was conducted to accommodate the need for peat moss land farmer group reinforcement program and to determine program priority scale to be done. Considering the program approved, the specified action activity was then implemented. Monitoring and evaluation was conducted to see the implementation of action program and to evaluate how far the action program contributes to the achievement of specified objective.

\section{RESULTS \& DISCUSSION}

\section{A. Peat Moss Land in Merbau Village.}

Merbau Village is the most east village in Bunut Sub District with geographical characteristics surrounded with forest. It is $34.75 \mathrm{~km} 2$ wide, with population number of 1100 people and population density of 32 productivity in dry farmland is 2.3 ton/hectare [6]. People utilize peat moss land for palm oil, rubber, rice, and palawija (secondary crop) farming. Although people has a local wisdom called "memurun", opening the land by means of cleaning and then burning on one point, this point begins to be abandoned along with the entry of many industrial forest companies that burn many peat moss lands. The culmination was the severest fire of peat moss land in Merbau in 2015 [7].

\section{B. The reinforcement of Farmer Group Capacity.}

The farmers in peat moss of Merbau Village are not accommodated in group, so that they operate palm oil, rubber, rice, and palawija farming activities individually. Peat moss land restoration program emphasizes on recovering peat moss land as the one buffering natural balance and not allowing it to be used for farming activities with commodities absorbing much water content such as palm oil and rubber. Merbau Village farmers have so long utilized peat moss for palm oil and rubber farming that a strategy is required to shift palm oil and rubber farming on peat moss to other commodities to replace palm oil and rubber in the futurefor farming activities with commodities absorbing much water content such as palm oil and rubber. Merbau Village farmers have so long utilized peat moss for palm oil and rubber farming that a strategy is required to shift palm oil and rubber farming on peat moss to other commodities. It is not easy recalling that palm oil and rubber are commodities that have been cultivated hereditarily. Considering the map of superior commodity ranking in Merbau, rubber and palm oil commodities become the primary ones, so that a strategy is required to develop other commodities to replace palm oil and rubber in the future

Table 1. Superior Commodity Ranking in Bunut Sub District, Pelalawan Pegency

\begin{tabular}{rcc}
\hline \multicolumn{1}{c}{ Value } & Commodity & Ranking \\
\hline $31,835,413$ & Rubber & 1 \\
$23,263,419$ & Palm oil & 2 \\
391,313 & Rice & 3 \\
67,778 & Swallow & 4 \\
7,452 & Honey & 5 \\
7,420 & Fresh Fish & 6 \\
7,270 & Chili & 7 \\
4,269 & Merchants & 8 \\
1,548 & Cucumber & 9
\end{tabular}

Source : Sutrisno et al, 2017

The strategy to support the replacement of palm oil land commodity should be taken by prioritizing PRA concept. PRA concept emphasizes on the importance of giving opportunity to the community as the actor of program to be carried so that this program is implemented in some stages.

\section{1) Need Analysis}

The type of program supporting peat moss restoration in Merbau Villagers was explored using focus group discussion (FGD). Considering the result of FGD, some information about action research forms of community empowerment and priority scale determination from the priority of program specified as presented in the table below.

Considering the result of FGD, 12 proposals of community empowerment activity are obtained for farmer group in Merbau Village in the attempt of supporting the development of alternative livelihood for peat moss farmers. Furthermore, out of the 12 proposals, 4 prioritized activities are determined corresponding to urgency level, dissemination, and resource availability. The top 2 rankings are selected consisting of 3 activities: farmer group development, Cassava SME's competitiveness improvement, and training for processed pineapple product diversification. Meanwhile other proposals are not selected because although the programs proposed are good, urgency level, resource availability and dissemination do not support their implementation. 
Table 2. Selection of Community Empowerment Activity Priorities in Merbau Village

\begin{tabular}{|c|c|c|c|c|c|c|}
\hline \multirow[b]{2}{*}{ No } & \multirow{2}{*}{ Need } & \multicolumn{3}{|c|}{ Priority Selection Criteria } & \multirow[t]{2}{*}{ Score } & \multirow[t]{2}{*}{$\begin{array}{c}\text { Priori } \\
\text { ty }\end{array}$} \\
\hline & & $\begin{array}{c}\text { Urgen } \\
\mathrm{t}\end{array}$ & $\begin{array}{c}\text { High } \\
\text { dissemination }\end{array}$ & $\begin{array}{c}\text { Resource } \\
\text { Ownership }\end{array}$ & & \\
\hline 1 & $\begin{array}{l}\text { Processed } \\
\text { (Nila and } \\
\text { lele) fish } \\
\text { products }\end{array}$ & 0 & 0 & 0 & 000 & $\mathrm{X}$ \\
\hline 2 & $\begin{array}{l}\text { Free- } \\
\text { range } \\
\text { chicken } \\
\text { breeding }\end{array}$ & 0 & 0 & 1 & 001 & $\mathrm{X}$ \\
\hline 3 & $\begin{array}{l}\text { Forest } \\
\text { Pandanus } \\
\text { Craft }\end{array}$ & 0 & 1 & 1 & 011 & $X$ \\
\hline 4 & $\begin{array}{l}\text { Instant } \\
\text { medicinal } \\
\text { herb } \\
\text { Developm } \\
\text { ent }\end{array}$ & 0 & 1 & 1 & 011 & $\mathrm{X}$ \\
\hline 5 & $\begin{array}{l}\text { Goat } \\
\text { Breeding }\end{array}$ & 0 & 0 & 0 & 000 & $\mathrm{X}$ \\
\hline 6 & $\begin{array}{l}\text { Processed } \\
\text { cassava } \\
\text { product } \\
\text { developm } \\
\text { ent }\end{array}$ & 1 & 1 & 1 & 111 & 1 \\
\hline 7 & $\begin{array}{l}\text { Processed } \\
\text { (tuakang, } \\
\text { lele) fish } \\
\text { products }\end{array}$ & 0 & 1 & 1 & 011 & $X$ \\
\hline 8 & $\begin{array}{l}\text { Wood } \\
\text { Tapping } \\
\text { or Planing }\end{array}$ & 0 & 0 & 1 & 001 & $X$ \\
\hline 9 & $\begin{array}{l}\text { Processed } \\
\text { plastic } \\
\text { waste }\end{array}$ & 0 & 0 & 1 & 001 & $\mathrm{X}$ \\
\hline 11. & $\begin{array}{l}\text { Processed } \\
\text { paludikult } \\
\text { ur } \\
\text { (pineapple } \\
\text { ) product }\end{array}$ & 1 & 0 & 1 & 101 & 2 \\
\hline 12 & $\begin{array}{l}\text { Farmer } \\
\text { group } \\
\text { developm } \\
\text { ent }\end{array}$ & 1 & 1 & 1 & 111 & 1 \\
\hline
\end{tabular}

Source : FGD of Merbau Village, October 2017

\section{2) Action Activity}

Considering the result of FGD, it can be found some local potencies of community to be developed, among others, through paludikultur introduction program, reinforcement of peat moss farmer groups, and cassava and pineapple potency development.

a. Paludikultur Pilot project.Paludikultur is the form of various plants enrichment and development on peat moss land (except sawit and rubber). Identification and characterization of soil's physical and morphological properties are important to do to determine the compatibility of plant to be cultivated [8]. In this program, the farmers voluntarily give their land to be the location of paludikultur pilot project as the form of its active role. The types of plant developed are, among others Arabica coffee, coconut, areca nut, banana, and pineapple developed on shallow, medium, and deep peat moss lands. Farmers participate actively in the process of opening land, planting, and maintaining (currently).

b. The reinforcement of Merbau Jaya Farmer Group. Actually, Farmer Group in Merbau Village has been established since a long time ago, but its condition is not active, even the field extension officer placed in Merbau Village comes rarely to facilitate the farmer group. This is because Merbau Jaya farmer group focuses on rice farming only, so that when rice farming has no longer been operated by farmers, the facilitation activity ceases as well. Since the enactment of the prohibition from opening land by burning it, rice farmer activity in Merbau Village also ceases. Merbau Village farmers assume that without land fire, rice farming will take much additional cost. Paludikultur activity needs support to reinforce the farmer group institution involved within it in order to implement the program sustainable.

Peat moss farmers are collected in the membership of "Merbau Jaya" farmer group having a philosophy as the group that will bring its members into prosperity. This farmer group's members consist of 32 persons divided into 3 land ownership areas: shallow (Coordinator: Mardiyanto), medium (coordinator: Mardan), and deep peat moss land groups (coordinator: Sofian Arisman).

The establishment of farmer group and its structure is conducted consciously by farmers facilitated by facilitator team. The structure is selected democratically in which the farmers hold a discussion to select head, secretary, treasurer and coordinators of each land area. The characteristics taken into consideration by the participants of discussion in determining the criteria of farmer group's head are young, innovative, adroit, and able of motivating/convincing the members to keep developing. The reinforcement of Merbau Jaya farmer groups is conducted, among others, by educating the members about the importance of establishing a group and administration of farmer group. A facilitator presented is field extension officer and the farmer group is expected to receive sustainable building in the future.

The important factor related to participation consists of external (the role of extension officer and social environment support such as support from community leader, group's role, information media, and government's role) and internal factors such as education level and income. To improve public (community) participation, the even distribution of extension officer's role and the government's active role are required to build and to practice the appropriate target [9]. Facilitation activity given by extension officer and other officers to the farmers affects significantly the improvement of farmer group's performance [10]. The strategy involving extension officer, village government and structure of regency government in developing Merbau Jaya farmer group is expected to improve the members' motivation to keep developing.

\section{c. Training for Processed Cassava and Pineapple Products.}

Cassava chip is one of small-scale processed food businesses operated by female farmer group in Merbau Village. Product development and the education about small- and medium-scale business management should be given to the group because the product they have produced so far is still simple and marketed in local area. The introduction of improved product competitiveness is conducted by providing training for producing balado cassava chip constituting the typical chip consumed to 
accompany padang and Malayan cooking needed widely in the food stalls existing in Riau and Pelalawan. In addition to product aspect, building is also given to group and business management aspects including how to process food well, practical bookkeeping, and innovation for small business. The female farmer group's active participation can be seen from the high presence level (90\%), activeness in paying attention to material and to ask question, participation in contributing infrastructures (place, raw material, consumption) and active role in training dynamics (role play, knowledge-experience exchange).

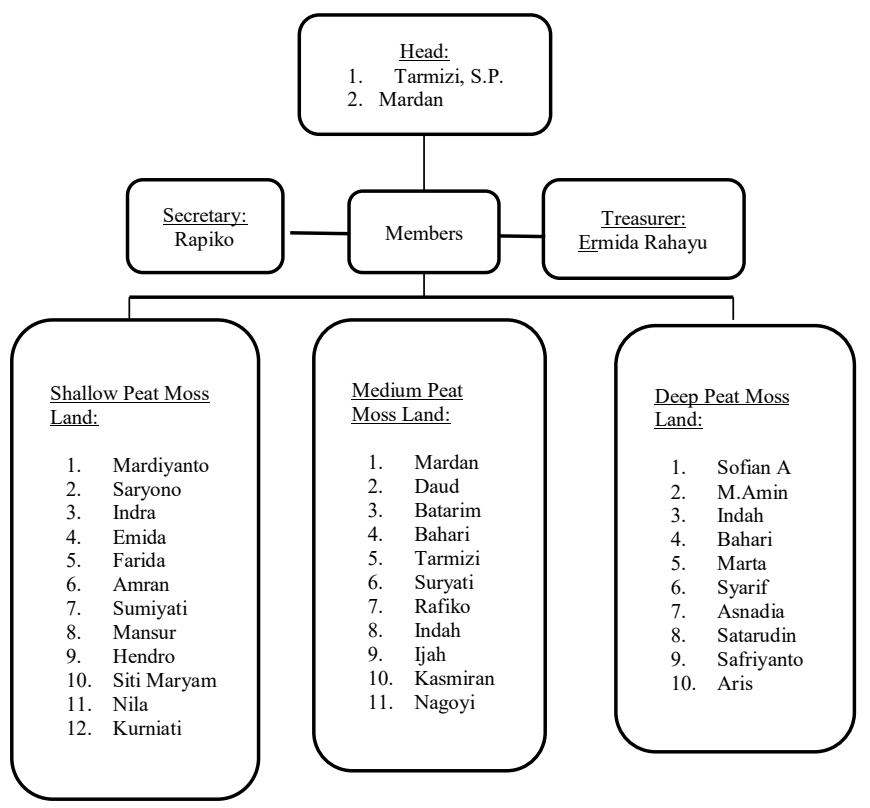

Figure 1. Organizational Structure of Merbau Jaya PeatMoss Farmer Group

Pineapple is a commodity not cultivated widely by peat moss farmers in Merbau Village. However, the good prospect of pineapple plant and its possibility to be a commodity developed in paludikultur program lead the farmers to take initiative to make pineapple one of materials necessarily delivered to construct the farmers' knowledge along with the pineapple cultivation process running in paludikultur land. The introduction of processed pineapple product is given including dry and wet pineapple sweets. In this training,

instead there are participants that can be facilitator for other participants by introducing "kolak nanas (pineapple compote)" product

The maturation of farmer group can actually be accomplished due to hard experience encountered that can keep the farmer group surviving amid various problems. The beach sand land farmer group in Kulon Progo that can develop into collective marketing organization in the form of auction market is established because the farmers' experience with the pressure of middleman's selling price for almost 20 years. Such condition led the farmers to take initiative to create a strategy of resisting the middleman's domination through collective marketing system. The existence of auction market can lead the farmers to have strong bargaining position in the last 14 years before the middleman. This innovation is diffused well among farmer groups along coastal areas in Kulon Progo Yogyakarta without external intervention.

This reinforcement of peat moss land farmer group faces distinctive challenge when in reality the farmers are highly dependent on external parties (in this case Peat Moss Land Restoration Agency and UNS) so that it is worried that restoration program implemented is limited to short-term project only, the effect of which is not sustainable in general.

Thus, facilitation from external parties should be continued sustainably until the farmer groups can grow and develop initiative internally. This study shows that the reinforcement of farmer group through external figures can accelerate the achievement of specified program or objective. In this case, the role of agricultural extension officer affects

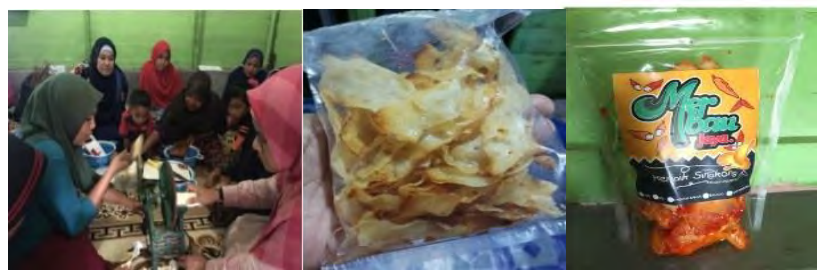

Figure 2. Balado Chip Process

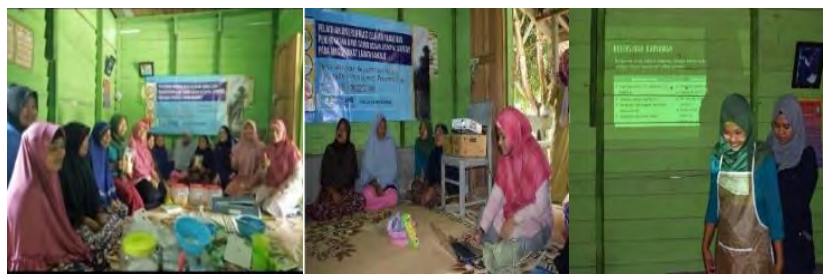

Figure 3. Role Play of Hygiene in Food Processing

\section{CONCLUSION}

The reinforcement of farmer behavior in peat land restoring program can be improved through the following programs:

(1) non-oil palm and rubber farming plant enrichment pilot project (paludikultur) that is peat land-friendly,

(2) the establishment of Merbau Jaya farmer group (deep, medium, and shallow peat land farmer groups), and

(3) the reinforcement of new livelihood based on cassava and pineapple local potencies (the reinforcement of SME institution and training for paludikultur processed product diversification

\section{ACKNOWLEDGMENTS}

The author expresses his gratitude to Peat Moss Restoration Agency for funding this activity and the people of Merbau Village, Bunut, Pelalawan, Riau for their active participation.

\section{REFERENCES}

[1] Suriadikarta, Didi Ardi. 2009. Learning from The Failure of A million hectare land development area management toward the sustainable peat moss land. Jurnal Pengembangan Inovasi Pertanian (J. Farm Inn Dev) 2 (4). 2009: 229-242 
[3] Adimihardja, Abdulrachman. 2006. Strategy of Maintaining Farming Multifunction in Indonesia. Jurnal Litbang Pertanian (J. Farm Res and Dev), 25 (3), 2006

[5] Rochdyanto, S. 2000. Procedure of Implementing PRA Method. Paper ToT PKPI. Yogyakarta.

[6] Pelalawan Statistics Center Bureau.2017. Pelalawan in Figures 2017. BPS Pelalawan.

[7] Sutriso, J, E.S.Rahayu, E.Antriyandarti, N.Setyowati, I.Khomah, E.Rusdiyana. 2017. Analysis on Peat Moss Land Community Livelihood in Pelalawan Regency. Research Report. Faculty of Agriculture of UNS

[8] Djaenudin, D., Y. Sulaeman, and A. Abdurachman. 2002. Teritorial Approach to farming commodity according to pedoagroclimate in Indonesian eastern area. Jurnal Litbang Pertanian (J. Farm Res and Dev) 21(1): 1-10.

[9] Sawerah, Siti, Mulyono Pudji, Tjiptopranoto Prabowo. 2016. Public Participation in Preventing the Fire of Peat Moss Land in Mempawah Regency. Jurnal Penyuluhan (J. Ext), March 2016 Volume 12 No 1

[10] Pribadi, Yanuar.2016. An Analysis on the Effect and the Effectiveness of Facilitation on PTT Technology Adoption and Wet Farm Rice in Gambut Sub District, South Borneo. Prosiding Seminar Nasional Inovasi Teknologi Pertanian (Proceeding of National Seminar on Farming Technology Innovation). Banjarbaru, July 202016 